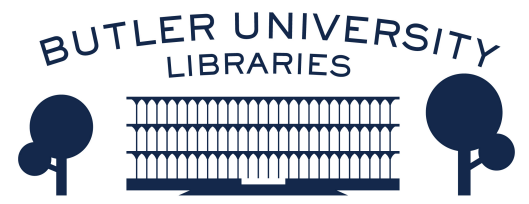

Journal of Hindu-Christian Studies

Volume 23

Article 18

January 2010

\title{
Book Review: "Transcendent in America: Hindu-Inspired Meditation Movements as New Religion"
}

Eliza F. Kent

Follow this and additional works at: https://digitalcommons.butler.edu/jhcs

Part of the Religion Commons

\section{Recommended Citation}

Kent, Eliza F. (2010) "Book Review: "Transcendent in America: Hindu-Inspired Meditation Movements as New Religion"," Journal of Hindu-Christian Studies: Vol. 23, Article 18.

Available at: https://doi.org/10.7825/2164-6279.1470

The Journal of Hindu-Christian Studies is a publication of the Society for Hindu-Christian Studies. The digital version is made available by Digital Commons @ Butler University. For questions about the Journal or the Society, please contact cbauman@butler.edu. For more information about Digital Commons @ Butler University, please contact digitalscholarship@butler.edu. 


\section{Transcendent in America: Hindu-Inspired Meditation Movements as New Religion. Lola Williamson. New York: New York University Press, 2010. xiii +261 pp.}

\section{LOLA Williamson's Transcendent in America:} Hindu-Inspired Meditation Movements as New Religion is a welcome addition to a wealth of recent scholarship examining the transmission of Hinduism or Hindu-inspired practices to the United States. The yoga boom has been the subject of numerous lengthy monographs and a favorite topic in North American mass media as well, with regular stories on everything from the latest urban yogi fashions to copyright squabbles among celebrity yoga teachers. A less noticed, but equally significant trend, are the steady numbers of people attracted to Hindu practices that foster not the body's flexibility and strength, but the mind's ability to achieve extraordinary states of consciousness through meditation. Transcendent in America examines three popular movements that teach various forms of meditation: the Self-Realization Fellowship (SRF), Siddha Yoga Dham of America, and Transcendental Meditation (TM). Williamson's study provides insight into the way Hinduism is adapted in the US with its religious culture so deeply influenced by Protestant Christian values and practices, especially its privileging of direct religious experience. However, 'I am not convinced it entirely succeeds as an in-depth examination of the mutual influence and interplay between Hinduism and Christianity in these movements, or of the complex power dynamics between religious teachers and students.

Defining Hindu-Inspired Meditation Movements (HIMMs) as a "new hybrid form of religion.... [that] combines aspects of Hinduism with Western values, institutional forms, modes of teaching, and religious sensibilities," (ix) Williamson recognizes that the term is an exogenous neologism that seeks to capture similarities among what people who participate in such groups often see as starkly different, even competing paths towards self-realization and enlightenment. Yet the features they have in common are significant. These include a shared ritual practice (meditation), a shared goal (distinctive states of consciousness described variously as "liberation, enlightenment or unity consciousness" [5]), and a shared commitment to the notion that gurus, sublime teachers who have themselves attained these extraordinary and utterly transformative states of consciousness, are essential in leading ordinary people towards that goal.

The book is divided into three parts. The first part provides background for understanding these movements. Chapter one fleshes out the conceptualization of these groups as belonging to a single type of American new religion by summarizing the elements they draw from Hindu traditions on the one hand and absorb from the surrounding Protestant Christian religious culture on the other. In chapter two, Williamson lends perspective to the emergence of HIMMs in the late twentieth century by investigating the historical contexts that have given rise to the popularity of "exotic" teachers from the East ever since Vivekananda's wildly successful debut at the 1893 World Parliament of Religions in Chicago. The second part of the book investigates the history, practices and worldview of the three movements that are the focus of the study. In the third part of the book, "In Their Own Words," Williamson draws on extensive interviews with adherents of these movements to examine their experiences of and reflections on the guru-disciple relationship, the "mind-blowing" mystical experiences that resonate so deeply with nearly all the practitioners interviewed, and the overall worldview that makes meaningful their sometimes decades-long commitment to begin each and every day with a prolonged period of meditation.

Transcendent in America is peppered with tantalizingly brief discussions of the interplay between Christianity and Hinduism in these movements - e.g. in the teachings of gurus like Paramahamsa Yogananda (founder of the SRF) 
who came to the US in 1920 to "teach yoga and the harmony between Krishna and Christ," and in the interpretative frameworks brought to these movements by people raised in Christian (and Jewish) families. But these do not accumulate into a sustained investigation into that interplay. In large part, this is because Williamson's main methodological concerns lie elsewhere.

One of the most thought-provoking aspects of the book is its engagement with insider/outsider questions in the study of religion. Williamson announces from the start her own involvement with TM for ten years and Siddha Yoga for twenty-two years. When she began research for the book as a Ph.D. student she was a devout disciple of Gurumayi. But when her fieldwork among current and exmembers of Siddha Yoga turned up mounting evidence of manipulation and abuse by leaders within the movement, including the supposedly enlightened founder-guru, Sri Muktananda, her idealism turned to bitterness. A recurring theme in the book is her effort to reconcile an appreciation for the manifold benefits she, and many other people, have experienced through meditation, and gratitude for the teachers who act as guides on the way, with evidence of widespread and recurring abuse within these movements. While Williamson is to be commended for her great empathy for her subjects, I was left ultimately disappointed by her reluctance or inability to go more deeply into one of the central questions of her book: Why is the phenomenon of abuse "endemic to many of these groups"?

The absence of a more critical methodology is also felt in her investigations of extraordinary mind-body states achieved through meditation practices. The chapter on "Mystical Experiences" consists mostly of lengthy first- person accounts of unusual physical, emotional and cognitive phenomena people experienced while meditating or receiving shaktipat (the transmission of spiritual energy from gurus to disciples). William James, Abraham Maslow and other practitioners of various hermeneutics of appreciation are recruited to help make sense of these. Theorists inclined to interpret these experiences as effects of other, sociological or material causes (i.e. "reductionists," or "skeptics"), however, are entirely neglected. Williamson's reluctance to use more robust hermeneutics of suspicion in her analysis of mystical phenomena is connected, in my view, to her inability to generate a convincing explanation for the phenomena of abuse found in these, and I hasten to note, many, many other religious communities. Perhaps the cause of these highly valued experiences is tremendous social pressure and heightened psychological expectations. The authority granted to people whom one thinks are responsible for inducing them may lead a person to doubt his or her own feelings of being mistreated, and to deny the testimonies of others. It is not hard to see how this package could foster an unhealthy environment that suppresses dissent in a community, whatever its religious or ideological worldview.

In spite of my reservations, I actually would recommend this book for inclusion in a course on diaspora Hinduism, or living Hinduism. Given its lively use of sources and the author's positionality, the book raises important questions about authority, religious experience and abuse, even if the answers it gives are not ultimately satisfying.

Eliza F. Kent

Colgate University

\section{South Asian Christian Diaspora. Edited by Knut Jacobsen and Selva Raj. Cornwall: Ashgate, 2008, 267 pp.}

Within the field of diaspora studies, one area which has received remarkably little attention is that of South Asian Christian diaspora. In the introduction to this volume, which has so far received little attention, is that of South Asian Christian diaspora. In the introduction to this volume, Selva Raj and Knut Jacobson, the editors, reflect at some length on the reasons for 